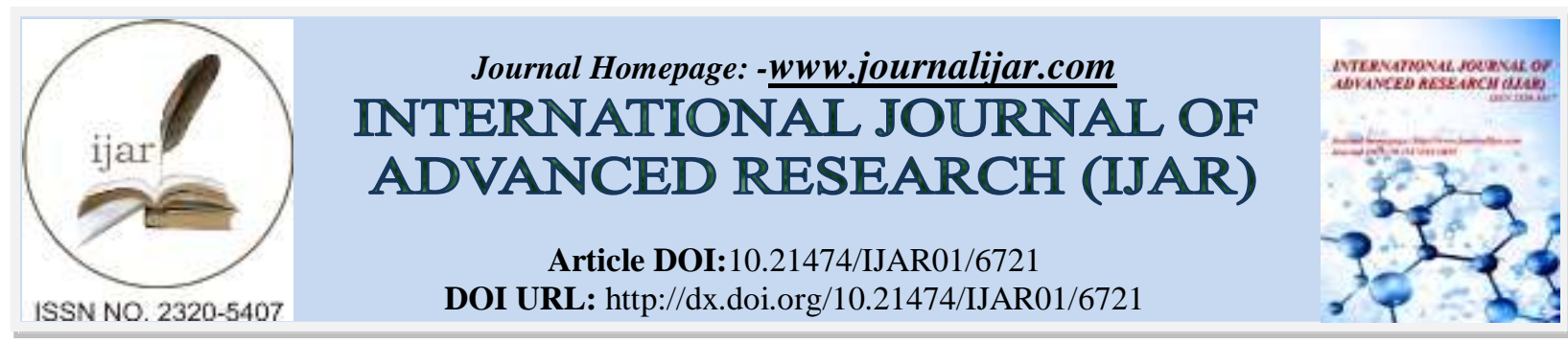

RESEARCH ARTICLE

\title{
CHEMOPROTECTIVE ACTIVITY OF OROXYLUM INDICUM VENT. ROOT BARK AGAINST CYCLOPHOSPHAMIDE MEDIATED MYELOSUPPRESSION AND ORGAN INJURY.
}

\author{
Seema Menon ${ }^{1}$, Lincy Lawrence ${ }^{1}$, Noby John ${ }^{2}$ and Jose Padikkala ${ }^{1}$.
}

1. Amala Cancer Research Centre (Recognized research centre of University of Calicut), Amala Nagar, Thrissur 680555 , Kerala.

2. The Erode College of Pharmacy and Research Institute, Vallipurathanpalayam P.O., Erode 638112, Tamil Nadu.

\section{Manuscript Info}

(..........................

Manuscript History

Received: 11 January 2018

Final Accepted: 13 February 2018

Published: March 2018

Keywords:-

Oroxylumindicum Vent.,chemoprotection , cyclophosphamide.

\section{Abstract}

The study investigated the chemoprotective effect of root bark of Oroxylum indicum Vent., against cyclophosphamide (CTX) induced myelosuppression and oragn injury in BALB/c mice. Four groups of 6 animals each- normal, untreated negative control group and animals treated with $O$. indicum Vent. root bark $70 \%$ hydro methanolic extract at low (OIML- $200 \mathrm{mg} / \mathrm{kg}$ b.wt.) and high doses (OIMH- $400 \mathrm{mg} / \mathrm{kg}$ b.wt.) respectively for 20 consecutive days were used for the study. Intra-peritoneal injection of CTX at a dose of $20 \mathrm{mg} / \mathrm{kg}$ on consecutive days, from day 6 to 15 was given for toxicity induction in all animals except normal. The body weight changes, hemoglobin level, total leucocyte count and bone marrow cellularity of animals in all groups were tracked periodically. After 120 hours of last CTX injection, mice were sacrificed; blood was collected to analyse serum markers of hepatic and renal function. The antioxidant status of liver and renal tissues based on SOD activity, GPx activity, reduced glutathione level and inhibition of lipid peroxidation were studied. The organo-somatic index (relative organ weight) of spleen as well as histological examination of intestine was determined in animals of all groups. Opposed to the devastating effect of CTX in hematological profile, bone marrow cellularity and relative spleen weight of untreated control group, the OIM treated animals showed significant restoration of these parameters into normalcy. OIM treatment also revealed better antioxidant profile and intestinal histological features, in comparison to the untreated control group, revealing its in vivo chemoprotective property.

Copy Right, IJAR, 2018,. All rights reserved.

\section{Introduction:-}

Cyclophosphamide (CTX) is a common alkylating anti-neoplastic drug used for the treatment of breast cancer, lymphomas, leukemias, neuroblastoma, retinoblastoma, rhabdomyosarcoma and many solid tumors of breast, gonads and lung (Colvin, 2003). Still, it poses serious side effects like cardiac toxicity, hematopoietic depression, hemorrhagic cystitis, gonadal dysfunction, alopecia, nausea, gastrointestinal toxicity, renal toxicity, anti-diuresis and vomiting (Slavin et al., 1975). It has been cytotoxic to normal cells in humans as well as experimental animals 
(Fraiser et al., 1991), with the haematopoietic compartment of bone marrow as the most affected part, leading to immunosuppression. CTX administration at high doses is also associated with the development of hepatotoxicity (Subramaniam et al., 2013), nephrotoxicity and genotoxicity (Rehman et al., 2012). CTX disrupts the redox balance of tissues, thereby succumbing them to biochemical and physiological damages and hence, agents with antioxidant properties can bring down cyclophosphamide-mediated organ injury (Mathew and Kuttan, 1997, Abarikwu et al., 2012). Recent researches focus on the development of plant-based drugs that can ameliorate the toxicity induced by CTX, but at the same time, retain its antineoplastic effect (Kumar and Kuttan, 2005b). As defined by the National Institute of Health, U.S., a chemoprotective agent protects normal tissues from the side effects caused by various anticancer drugs (e-Article, 2016). The study investigates the chemoprotective activity of a medicinal tree, Oroxylum indicum Vent. root bark extract in CTX induced animals, by evaluating its ability to reduce myelosuppression, hepatic, renal and intestinal mucosal injuries.

O. indicum Vent., known as Shyonaka in Sanskrit (Kapoor, 1990) is one among the ten plants whose roots form ingredients of the widely used Ayurvedic formulation, Dashamoola, which literally means 'ten roots'. A study previously done on $O$. indicum Vent. has disclosed that the different parts of the plant like leaves, fruits, stem, stem bark, roots and root bark possess in vitro free radical scavenging activities (Mishra et al., 2010). The ethyl acetate, methanolic, and aqueous extracts of the leaves are reported to be anti-oxidant in nature (Gupta et al., 2008). In sodium fluoride induced oxidative stress induced models, treatment with $70 \%$ methanolic extract of $\mathrm{O}$. indicum Vent. root bark at dosages of 200 and $400 \mathrm{mg} / \mathrm{kg}$ b.wt showed significant amelioration in stress as reported previously by the authors (Menon et al., 2015). The use of anti-oxidants during chemotherapy can reduce oxidative stress induced by anticancer therapeutics (Conklin, 2004). The objective of the study is to investigate chemoprotective effect of $O$. indicum Vent. root bark in CTX induced models, being previously unexplored, besides considering its anti-oxidant properties as cited before.

\section{Materials and methods:- \\ Collection and preparation of plant extract}

The roots of $O$. indicum Vent. were collected in the month of August from the Ayurvedic Garden belonging to Amala Cancer Hospital campus, Thrissur, Kerala, India, and was authenticated by Dr. P. Sujanapal, Scientist- B, Silviculture Department, KFRI, Peechi, Thrissur 680 653, Kerala (Voucher specimen No: KFRI/SILVA/GEN/06/11). The peeled bark was dried at $45^{\circ} \mathrm{C}$ in hot air oven, powdered and subjected to extraction using $70 \%$ methanol as solvent. A dry residue (OIM) was obtained by filtration, concentration and evaporation of the extract. This was re-dissolved in distilled water and used for in vivo studies.

\section{Chemicals and diagnostic kits}

Cyclophosphamide was purchased from Sigma-Aldrich Inc., St Louis, USA; diagnostic kits for the estimation of Glutamate oxaloacetate transaminase (GOT), Glutamate pyruvate transaminase (GPT) and Alkaline phosphatase (ALP) from Span Diagnostics Ltd., Gujarat, India ; kits for estimation of creatinine and urea from Euro Diagnostic Systems Pvt. Ltd., Chennai, India ; and kit for hemoglobin estimation from Agappe Diagnostics Ltd., Ernakulam, Kerala, India. Nitro blue tetrazolium (NBT), 5-5'Dithiobis 2-nitrobenzoic acid (DTNB), reduced glutathione and riboflavin [purchased from Sisco Research Laboratories (SRL) Pvt. Ltd., Mumbai, India], Ethylene diamine tetra acetic acid (EDTA), sodium dodecyl sulphate (SDS) and hydrogen peroxide (from E-Merck India PvtLtD, Mumbai, India) and thiobarbituric acid (from Himedia Laboratories Pvt. Ltd, Mumbai, India) were used for estimating the tissue antioxidant parameters. All other chemicals used were of analytical grade.

\footnotetext{
Animals

BALB/c (22-25 g) mice were purchased from the Small Animal Breeding Station, Kerala Veterinary and Animal Sciences University, Thrissur, Kerala, India. The animals were kept in well-ventilated polypropylene cages under standard conditions: temperature $\left(22^{\circ} \mathrm{C}-25^{\circ} \mathrm{C}\right)$, relative humidity $(60 \%-80 \%)$, and light-dark cycle of 12 hours. Animals were fed with mouse feed (SAI Durga Food and Feeds, Bangalore, India) and water ad libitum. All animal experiments conducted during the present study were with prior permission from Institutional Animal Ethics Committee, Amala Cancer Research Centre (Approval No. ACRC/IAEC/15/02-(01)) and strictly followed the guidelines of Committee for the Purpose of Control and Supervision of Experiments on Animals (CPCSEA) constituted by the Animal Welfare Division, Government of India.
} 


\section{Grouping of animals}

Four groups of 6 animals each were maintained according to the treatment protocol. Group I served as normal reference group. Group II served as the untreated negative control group, exposed to CTX. Groups III and IV were the extract treated groups receiving oral administration of OIM extract at low (OIML- $200 \mathrm{mg} / \mathrm{kg}$ b.wt.) and high doses (OIMH- $400 \mathrm{mg} / \mathrm{kg}$ b.wt.) respectively for 20 consecutive days. For each group, three sub-groups with 6 animals were maintained to enumerate the bone marrow cellularity on initial day, $7^{\text {th }}$ day and $4^{\text {th }}$ day.

\section{Cyclophosphamide induction}

Induction of toxicity was done in all the groups except I, by intra-peritoneal injection of CTX at a dose of $20 \mathrm{mg} / \mathrm{kg}$ of animal body weight as i.p. on consecutive days, from day 6 to 15 (Kumar and Kuttan, 2005a).

\section{Parameters studied}

The body weight changes of animals in all groups were tracked periodically in every $5^{\text {th }}$ day of the study. On every $5^{\text {th }}$ day of the study, blood was collected into heparinized tubes by caudal vein puncture to track the hematological parameters of blood - [hemoglobin level (Drabkin and Austin, 1935) and total leucocyte count (Chesbrough and Arthur, 1972)] periodically. On the initial day, $7^{\text {th }}$ day, $14^{\text {th }}$ day and the final day (immediately after sacrifice), bone marrow cells from both the femurs were collected by flushing out using PBS containing $10 \%$ fetal bovine serum (FBS). The total live cell count was determined using a hemocytometer and expressed as ' $\mathrm{n}$ ' $\left(\times 10^{6}\right) / \mathrm{femur}$.

\section{Evaluation of renal and liver function markers in serum}

On day 20 (120 hours after last Cis injection), mice were sacrificed; blood was collected by heart puncture into nonheparinised vials to collect serum. Serum markers of hepatic and renal function - GOT, GPT, ALP, creatinine and urea were analyzed to evaluate the extent of liver and kidney tissue damage.

\section{Evaluation of lipid peroxidation level and antioxidant status in hepatic and renal tissue}

$10 \%(\mathrm{w} / \mathrm{v})$ homogenates of renal tissue and hepatic tissues were prepared in ice cold $0.1 \mathrm{M}$ Tris-HCl. Lipid peroxidation measured as MDA level in the tissue homogenate was analyzed according to the method of Ohkawa $e t$ al. (1979). The cytosolic fraction of the tissue homogenate was used for studying the antioxidant status based on SOD activity (McCord and Fridovich, 1969), GPx activity (Hafeman et al., 1974) and reduced glutathione level (Moron et al., 1979).

\section{Determination of organo-somatic index of spleen}

The organo-somatic index (relative organ weight) of spleen was determined in animals of all groups.

\section{Histopathological examination of intestine}

After the sacrifice of animals, intestine was excised using sterilized scissors and washed with normal saline (0.9\% $\mathrm{NaCl}$ ) and fixed in $10 \%$ neutral buffered formalin. After dehydration and embedding, sections of thickness varying from 3-4 $\mu \mathrm{m}$ were made in a microtome and subjected to hematoxylin/eosin double staining. The slides were observed under light microscope (100 x) and photographed.

\section{Statistical analysis}

The values were expressed as mean \pm SD of 6 animals per group. Statistical evaluation of the data was done by one way ANOVA followed by Dunnett post hoc test using Graph Pad Instat 3 software. Results were considered statistically significant when $\mathrm{p}$ value was $<0.05$.

\section{Results:-}

\section{Changes in body weight}

As seen from figure 1, progressive reduction was noticed in the average body weight of animals injected with cyclophosphamide alone (negative control group), from the initial day of CTX administration (31.08 $\pm 1.3 \mathrm{~g}$ ) to the day of sacrifice $(26.02 \pm 0.8 \mathrm{~g})$. The normal reference group showed no noticeable body weight loss. In the OIML group also, there was a slight decline of average body weight from day $5(29.34 \pm 1.4 \mathrm{~g})$ to $20(26.4 \pm 1.0 \mathrm{~g})$. But, in the OIMH group, only negligible change was recorded in body weight from day 5 (30.84 $\pm 1.2 \mathrm{~g}$ ) to day 20 (29.514 $\pm 1.0)$. 


\section{Changes in haemoglobin level and total leucocyte count}

Figure 2 shows the change in hemoglobin level of blood in CTX induced animals over the period of study. The CTX induced control group, having received no pre-treatment, suffered slight reduction of blood Hb level from the day of CTX induction $(12.87 \pm 0.37 \mathrm{~g} / \mathrm{dL})$ until sacrifice $(12.36 \pm 0.37 \mathrm{~g} / \mathrm{dL})$, though statistically non significant. However, the $\mathrm{Hb}$ values recorded in OIML $(12.67 \pm 0.1$ to $12.59 \pm 0.4 \mathrm{~g} / \mathrm{dL})$ and OIMH $(12.89 \pm 0.1$ to $12.69 \pm 0.5 \mathrm{~g} / \mathrm{dL})$ groups were only within a narrower range after CTX administration up to sacrifice.

The tracking of mean total leucocyte count in CTX administered animals is shown in figure 3 . When the normal reference group not exposed to CTX showed no significant changes, the untreated negative control suffered drastic and significant decline in WBC count from day $5\left(13033 / \mathrm{mm}^{3}\right)$ to day $20\left(6290 / \mathrm{mm}^{3}\right)$. OIML group also suffered such decline in WBC count from $12883 / \mathrm{mm}^{3}$ to $8050 / \mathrm{mm}^{3}$. But, treatment with OIM at high dose (OIMH) was demonstrated to withstand the myelosuppressive effect of CTX, as noted from non significant change in the total WBC count recorded from the $5^{\text {th }}$ day $\left(12633 / \mathrm{mm}^{3}\right)$ to $20^{\text {th }}$ day $\left(10360 / \mathrm{mm}^{3}\right)$.

\section{Changes in bone marrow cellularity}

The effect of OIM extract on resisting the myelosuppressive effect of CTX administration was also analyzed based on the weekly bone marrow cellularity track record. The normal reference group showed no notable change. But the CTX administered untreated negative control suffered reduction in 2 week period after CTX administration, from day $7\left(1149.22 \times 10^{4}\right.$ cells/femur) to $20\left(894.5 \times 10^{4}\right)$. OIM treatment at high dose (OIMH) withstood the effect of CTX, as the values recoded from day $7\left(1239.88 \times 10^{4}\right)$ to $20\left(1245.25 \times 10^{4}\right)$, an effect better than what observed with lose dose (OIML) $\left(1178.0 \times 10^{4}\right.$ on day 7 and $1067.75 \times 10^{4}$ on day 20). The changes in bone marrow cellularity in various groups are given in figure 4 .

\section{Renal and liver function markers in serum}

Table 1 shows the levels of renal and liver function markers in the serum of CTX administered animals. Compared to the normal reference group, all serum markers in the untreated control- GOT (129.17 $\pm 8.37 \mathrm{U} / \mathrm{L})$, GPT $(82.2 \pm$ $8.83 \mathrm{U} / \mathrm{L}), \operatorname{ALP}(84.97 \pm 6.63 \mathrm{U} / \mathrm{L})$, urea $(27.34 \pm 4.81 \mathrm{mg} / \mathrm{dL})$ and creatinine $(1.25 \pm 0.06 \mathrm{mg} / \mathrm{dL})$ got significantly $(\mathrm{p}<0.01)$ elevated, indicating hepatic and renal injury. But, these parameters were significantly $(\mathrm{p}<0.01)$ lower in OIMH group [GOT $(114.29 \pm 6.22 \mathrm{U} / \mathrm{L})$, GPT $(57.53 \pm 6.35 \mathrm{U} / \mathrm{L})$, ALP $(63.75 \pm 5.83 \mathrm{U} / \mathrm{L})$, urea $(17.47 \pm$ $3.92 \mathrm{mg} / \mathrm{dL})$ and creatinine $(0.91 \pm 0.036 \mathrm{mg} / \mathrm{dL})]$. Meanwhile, in the OIM low dose group (OIML), the serum markers - GPT $(69.22 \pm 6.99 \mathrm{U} / \mathrm{L})$, ALP $(72.32 \pm 4.62 \mathrm{U} / \mathrm{L})$ and urea $(20.55 \pm 3.94 \mathrm{mg} / \mathrm{dL})$ showed significant reduction too.

\section{Lipid peroxidation level and antioxidant status in hepatic and renal tissue}

Treatment with OIM enhanced the antioxidant status of the liver and kidney in CTX induced animals as seen in figure 5 and 6. From figure 5, it can be seen that in CTX induced negative control group devoid of extract treatment, the levels of SOD $(0.382 \pm 0.04 \mathrm{U} / \mathrm{mg}$ protein $)$, GPx $(7.15 \pm 0.43 \mathrm{U} / \mathrm{mg}$ protein $)$ and GSH $(13.63 \pm 1.42 \mathrm{nmoles} / \mathrm{mg}$ protein) in liver were significantly lower than that of normal. Similar trend was observed in the levels of these parameters in the renal tissue (SOD - $0.577 \pm 0.06$, GPx $-6.75 \pm 0.49$ and GSH $-15.83 \pm 2.12$ ) (figure 6). But in OIM treated high dose group (OIMH), levels of liver SOD $(0.571 \pm 0.04)$, liver GPx $(9.82 \pm 0.51)$, liver GSH (36.88 $\pm 2.61)$, renal SOD $(0.72 \pm 0.07)$, renal GPx $(10.2 \pm 0.52)$ and renal GSH $(27.24 \pm 2.03)$ were elevated significantly higher than untreated control.

When CTX administration increased the lipid peroxidation activity in liver $(0.412 \pm 0.03$ nmoles of MDA $/ \mathrm{mg}$ protein) and kidney $(0.42 \pm 0.03)$ in untreated control, they were comparatively lower in OIMH (liver- $0.28 \pm 0.02$; kidney- $0.25 \pm 0.02$ ) and OIML (liver- $0.36 \pm 0.02$; kidney- $0.27 \pm 0.02$ ) groups, with statistical significance, $\mathrm{p}<$ 0.01 .

\section{Organo-somatic index of spleen}

The impact of CTX administration on immune system was inferred on the basis of the organo somatic index of spleen, which was significantly very low in the untreated control $(0.251 \pm 0.016)$, with reference to normal; but was near normal in OIML $(0.303 \pm 0.016)$ and OIMH $(0.318 \pm 0.017)$ groups.

\section{Histopathology of intestine}

The histological sections of the intestine of normal mice showed typical structure, with regular villi and glands (Figure 7). The villi and glands are lined by columnar cells. The muscle layer also appeared normal. But, in the 
control animal intestine, the mucosal glands and villi showed hyperplasia, with considerable mucosal infiltration of lymphocytes. The muscle layer also showed inflammatory changes. In the OIML group intestine, though the villi appear normal, there were a few damaged areas in the mucosal layer. In the meantime, treatment with OIM extract at high dose had considerable protection on the intestinal mucosa and muscle layer, in spite of simultaneous CTX administration. This is evident from the presence of normal villi and mucosal glands, as revealed through histopathology. The muscle layer also appeared normal.

\section{Discussion:-}

The study has revealed the chemoprotective activity of $O$. indicum Vent. root bark against organ specific toxicity induced by CTX. Antioxidant pool of the liver and kidney reportedly undergoes depletion under the effect of CTX administration, as seen in earlier animal studies (Premkumar et al., 2003, Sheweita et al., 2016). Similar devastating effects on antioxidant defense were also observed in the untreated animals induced with CTX in the current study. But, on treatment with OIM, the antioxidant markers of liver and renal tissue maintained significantly higher levels than the negative control, seemingly resistant to the oxidative stress challenge posed by CTX. Though CTX increases the susceptibility of renal and hepatic tissues to increased lipid peroxidation (Bhattacharya et al., 2003, Stankiewicz and Skrzydlewska, 2003, Ray et al., 2011), plant extracts rich in antioxidants are found to be ameliorative against this effect (Ingale et al., 2013, Khan et al., 2014, Devi and Mazumder, 2016). Concomitant effects were produced by OIM treatment in this study.

By CTX induction, elevation of serum GPT and GOT levels shot up significantly, which were alleviated by OIM treatment. This is suggestive of hepatic injury. Moreover, these two inducers were demonstrated to cause renal tissue damage, as evident from the elevation of serum urea and creatinine levels in the untreated control. Yet, an overall ameliorative effect was observed in these effects by OIM treatment, as revealed from the sera profile of treated animals.

Common side effects associated with cancer chemotherapy are myelosuppression, immunosuppression and anaemia, because rapidly dividing normal cells of the body also form targets for chemotherapeutic drugs, besides cancer cells (Spivak et al., 2009). These effects have also been found true with CTX in experimental animals (Thews et al., 2001). The effects are manifested as drops in $\mathrm{Hb}$ and WBC count in blood, reduction in bone marrow cellularity and decrease in the relative weight of spleen (Begum and Anuradha, 2011, Ahmad et al., 2013, Neboh and Ufelle, 2015, Sakthivel and Guruvayoorappan, 2015). In the present study, CTX administration was found to affect WBC count significantly. CTX administration seemingly exerted its myelosuppressive effect on bone marrow of untreated CTX administered animals, evident from a significant and progressive reduction of bone marrow cellularity. Consequently, the relative organ weight of spleen, the secondary lymphoid organ was also found to be notably low in untreated control, in comparison with the normal. Such suppressive changes were evaded by the OIM treated animals, in a statistically significant level.

The biological properties of plant extracts are attributed to the synergistic action of the multifarious compounds present in them. $O$. indicum Vent.root bark reportedly contains baicalein, chrysin, biochanin A and ellagic acid. Chrysin (Pushpavalli et al., 2010, Veerappan and Senthilkumar, 2015), biochanin-A (Zhang et al., 2011) and ellagic acid (Warpe et al., 2015a) are compounds attributed with anti-oxidant properties. There are proven studies of chemoprotective properties of ellagic acid (Rehman et al., 2012, Warpe et al., 2015b). It is hence, conclusive that the presence of anti-oxidant compounds in the OIM extract may possibly have mediated the chemoprotective effects, through their combined action. Though it is not suggestive of an immediate clinical supplementation in humans undergoing chemotherapy for cancer, the study extends the scope of exploring active fractions from this plant extract for using it as an adjuvant in CTX- mediated chemotherapy, and thereby reduce the damaging side effects of these drugs, without compromising their cytotoxic activity.

\section{Conflicts of interest}

All authors have agreed for submission in the journal "International Journal of Advanced Research" and there exists no conflict of interest in this study.

\section{Acknowledgement:-}

The authors express gratitude to the Council of Scientific and Industrial Research, Government of India for the financial support in the form of Senior Research Fellowship (09/869 (0008)/ 2011-EMR-I). 
Figure 1:-Effect of OIM extract treatment on the average body weight of Cyclophosphamide induced animals (Values are expressed as mean \pm SD for 6 animals. SD: Standard deviation, OIM: $O$. indicum Vent. 70\% methanolic extract, OIML: $O$. indicum Vent. 70\% methanolic extract low dose, OIMH: $O$. indicum Vent. $70 \%$ methanolic extract high dose)

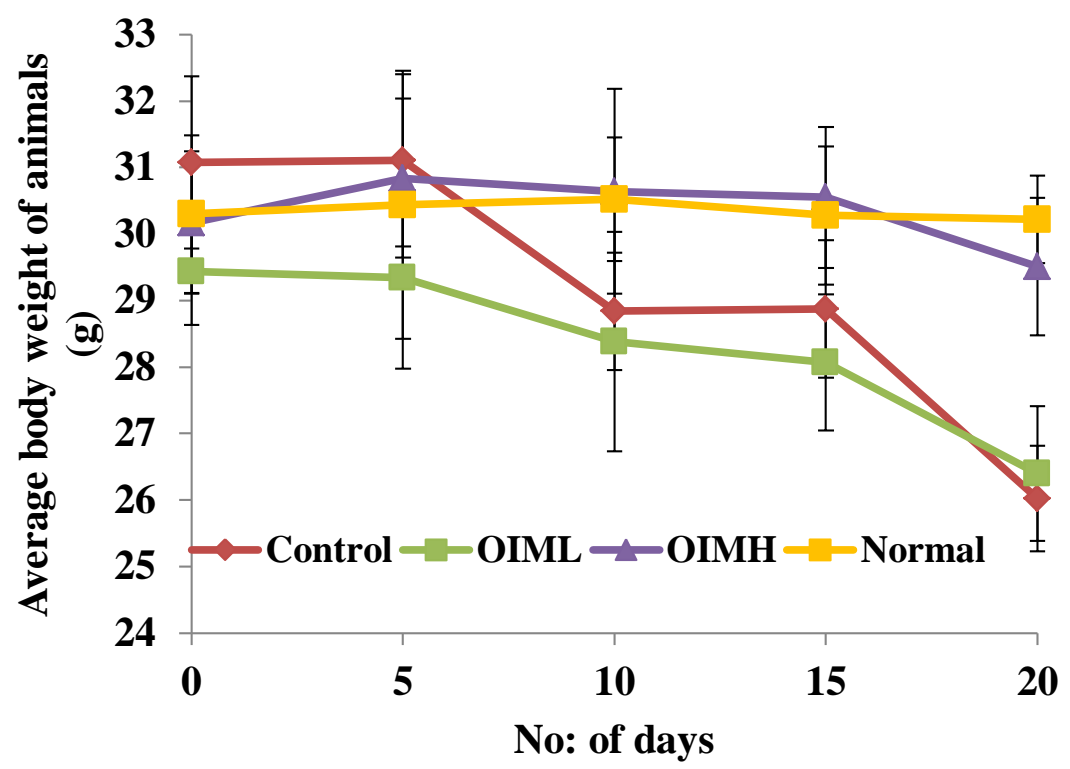

Figure 2:-Effect of OIM extract treatment on the average hemoglobin level of blood in Cyclophosphamide induced animals (Values are expressed as mean \pm SD for 6 animals. SD: Standard deviation, OIM: O. indicum Vent. 70\% methanolic extract, OIML: O. indicum Vent. 70\% methanolic extract low dose, OIMH: O. indicum Vent. 70\% methanolic extract high dose)

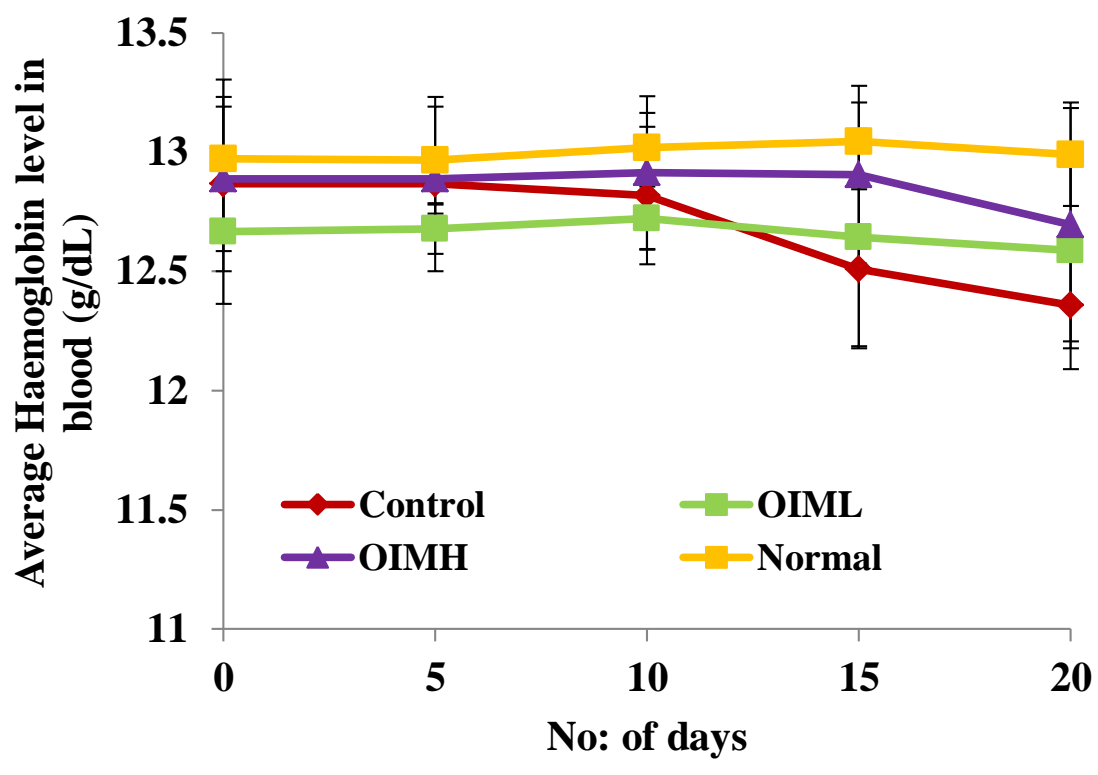


Figure 3:-Effect of OIM extract treatment on the average total leucocyte count of blood in Cyclophosphamide induced animals (Values are expressed as mean \pm SD for 6 animals. SD: Standard deviation, OIM: O. indicum Vent. 70\% methanolic extract, OIML: O. indicum Vent. 70\% methanolic extract low dose, OIMH: O. indicum Vent. 70\% methanolic extract high dose)

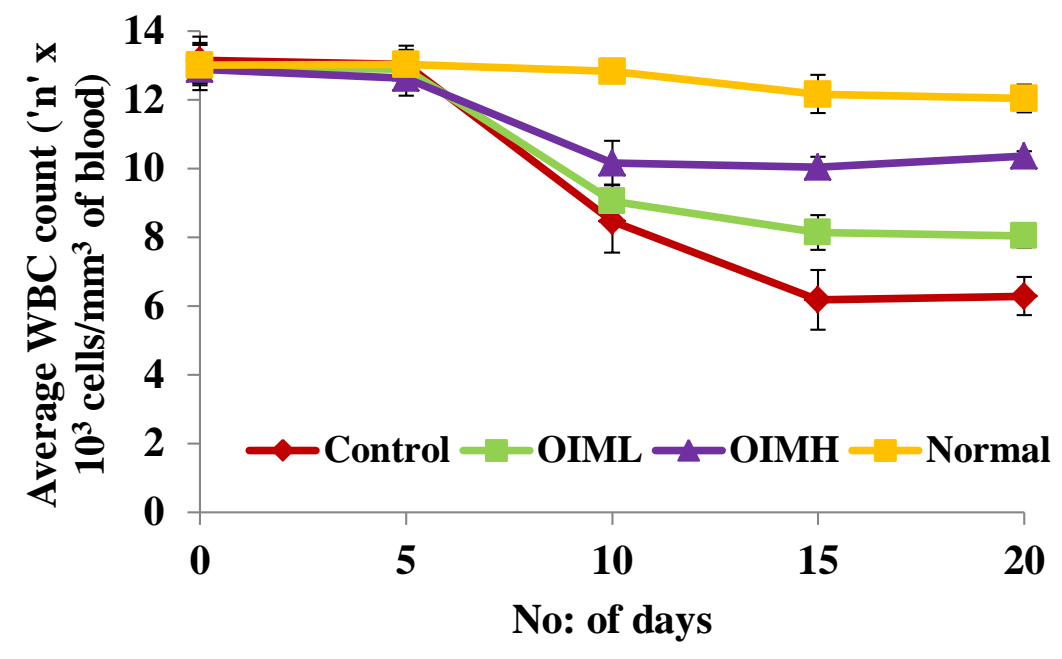

Figure 4:-Effect of OIM extract treatment on the average bone marrow cellularity in Cyclophosphamide induced animals (Values are expressed as mean \pm SD for 6 animals. SD: Standard deviation, OIM: O. indicum Vent. 70\% methanolic extract, OIML: O. indicum Vent. 70\% methanolic extract low dose, OIMH: O. indicum Vent. 70\% methanolic extract high dose)

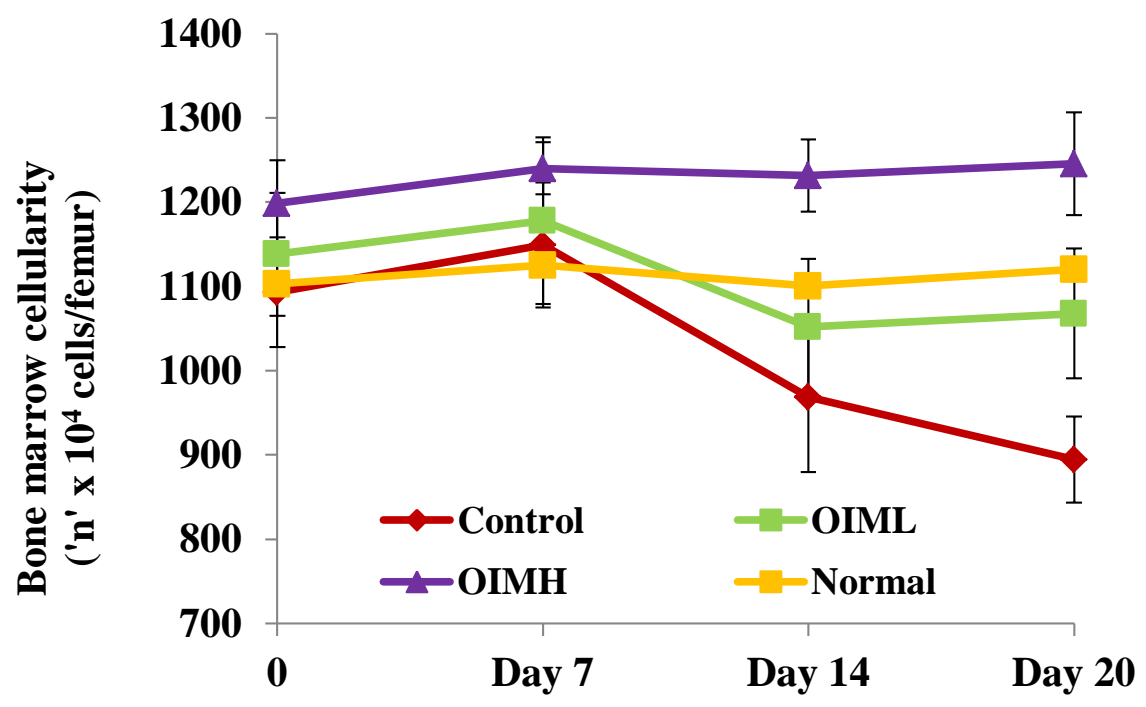


Figure 5:-Effect of OIM extract treatment on liver lipid peroxidation level and tissue anti oxidant status in cyclophosphamide induced animals. (OIM: $O$. indicum Vent. $70 \%$ methanolic extract, OIML: $O$. indicum Vent. $70 \%$ methanolic extract low dose, OIMH: $O$. indicum Vent. $70 \%$ methanolic extract high dose, SOD: Superoxide dismutase, GPx: Glutathione peroxidise, GSH: reduced glutathione, MDA: malondialdehyde)

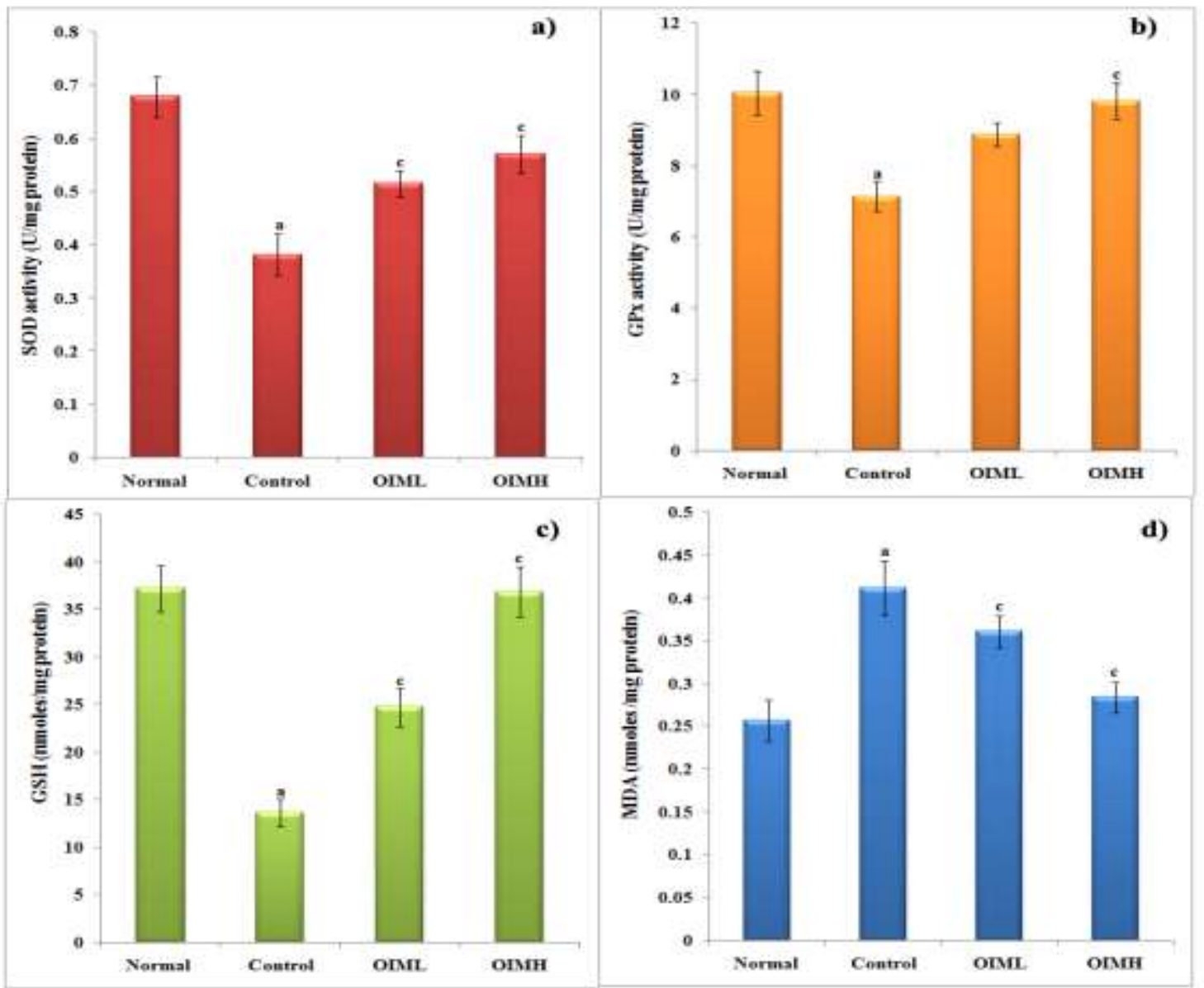

Values are expressed as mean \pm SD for 6 animals; ${ }^{a} \mathrm{p}<0.01,{ }^{b} \mathrm{p}<0.05$ compared to normal; ${ }^{\mathrm{c}} \mathrm{p}<0.01,{ }^{\mathrm{d}} \mathrm{p}<0.05$ compared to control. 
Figure 6.Effect of OIM extract treatment on renal lipid peroxidation level and tissue anti oxidant status in cyclophosphamide induced animals. (OIM: $O$. indicum Vent. 70\% methanolic extract, OIML: $O$. indicum Vent. 70\% methanolic extract low dose, OIMH: $O$. indicum Vent. $70 \%$ methanolic extract high dose, SOD: Superoxide dismutase, GPx: Glutathione peroxidise, GSH: reduced glutathione, MDA: malondialdehyde)

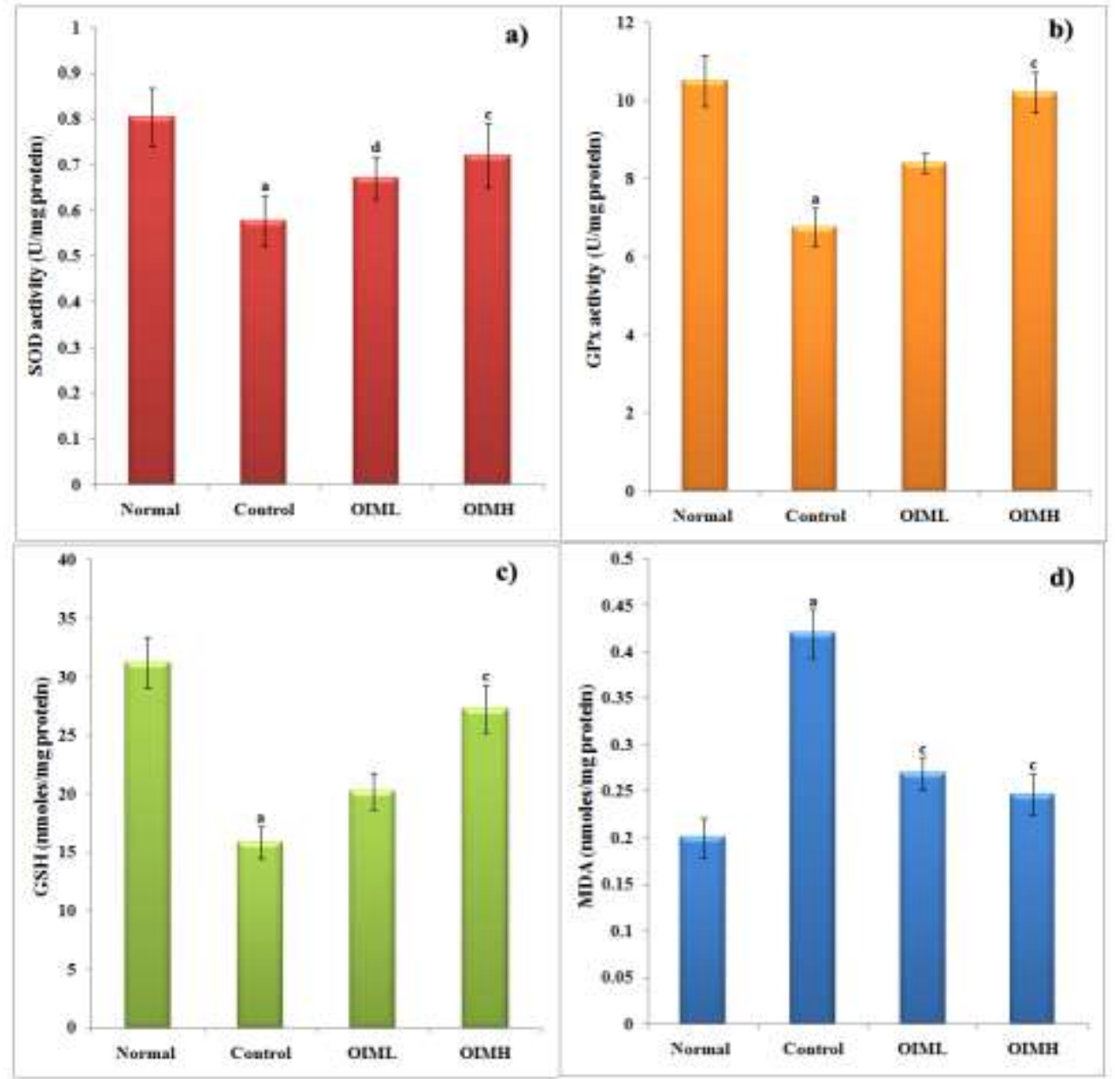

Values are expressed as mean \pm SD for 6 animals; ${ }^{a} \mathrm{p}<0.01,{ }^{b} \mathrm{p}<0.05$ compared to normal; ${ }^{\mathrm{c}} \mathrm{p}<0.01,{ }^{\mathrm{d}} \mathrm{p}<0.05$ compared to control. 
Figure 7:-Effect of OIM extract treatment on intestinal histopathology in cyclophosphamide induced animals. (OIM: O. indicum Vent. 70\% methanolic extract, OIML: O. indicum Vent. 70\% methanolic extract low dose, OIMH: $O$. indicum Vent. $70 \%$ methanolic extract high dose)

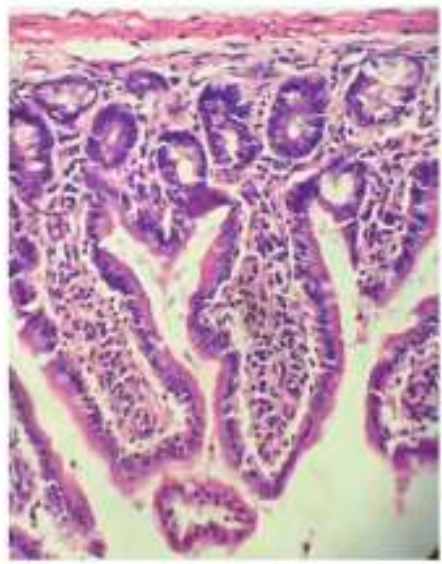

Normal

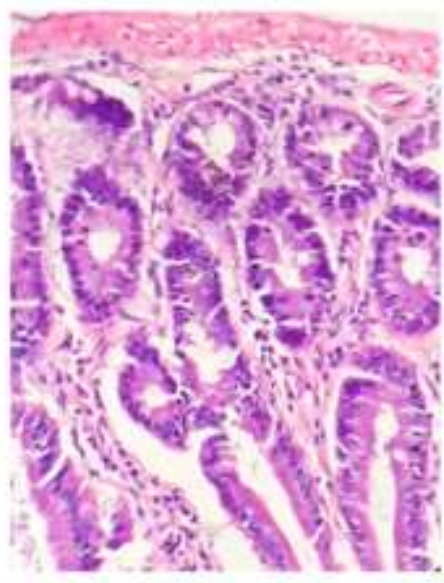

OIML

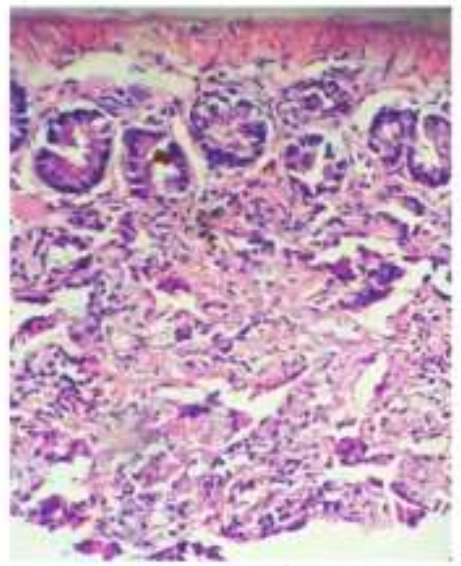

Control

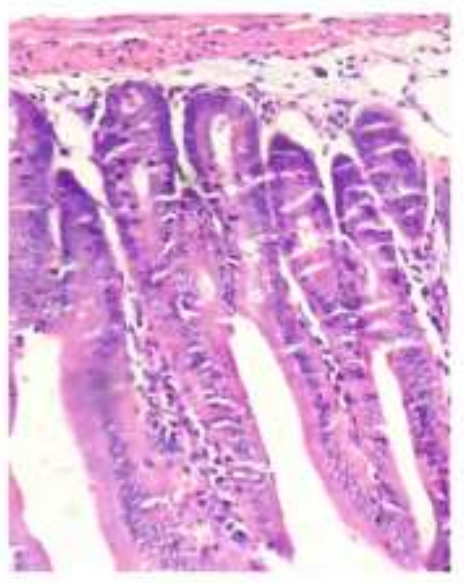

OIMH

Table 1:- Effect of OIM extract treatment on serum markers of liver and renal function in cyclophosphamide induced animals.

\begin{tabular}{|c|c|c|c|c|c|}
\hline Animal groups & GOT (U/L) & GPT (U/L) & ALP (U/L) & Urea $(\mathrm{mg} / \mathrm{dl})$ & $\begin{array}{l}\text { Creatinine } \\
(\mathrm{mg} / \mathrm{dl})\end{array}$ \\
\hline Normal & $108.23 \pm 6.19$ & $42.98 \pm 3.47$ & $60.22 \pm 4.74$ & $17.87 \pm 2.27$ & $0.67 \pm 0.03$ \\
\hline Control & $129.17 \pm 8.37^{\mathrm{a}}$ & $82.2 \pm 8.83^{\mathrm{a}}$ & $84.97 \pm 6.63^{\mathrm{a}}$ & $27.34 \pm 4.81^{\mathrm{a}}$ & $1.25 \pm 0.06^{\mathrm{a}}$ \\
\hline OIML & $124.97 \pm 7.29$ & $69.22 \pm 6.99^{c}$ & $72.32 \pm 4.62^{\mathrm{c}}$ & $20.55 \pm 3.94^{c}$ & $1.201 \pm 0.04$ \\
\hline OIMH & $114.29 \pm 6.22^{c}$ & $57.53 \pm 6.35^{c}$ & $63.75 \pm 5.83^{\mathrm{c}}$ & $17.47 \pm 3.92^{\mathrm{c}}$ & $\begin{array}{ll}0.91{ }^{c} & \pm \\
0.036 & \end{array}$ \\
\hline
\end{tabular}

Values are expressed as mean \pm SD for 6 animals.

SD: Standard deviation, OIM: O. indicum Vent. 70\% methanolic extract, OIML: O. indicum Vent. $70 \%$ methanolic extract low dose, OIMH: $O$. indicum Vent. 70\% methanolic extract high dose, GOT (Glutamate oxaloacetate transaminase), GPT (Glutamate pyruvate transaminase), ALP (Alkaline phosphatase)

${ }^{\mathrm{a}} \mathrm{p}<0.01,{ }^{\mathrm{b}} \mathrm{p}<0.05$ - control compared to normal; and ${ }^{\mathrm{c}} \mathrm{p}<0.01,{ }^{\mathrm{d}} \mathrm{p}<0.05$ - groups OIML and OIMH compared to control 


\section{Reference:-}

1. Abarikwu, S.O., Otuechere, C.A., Ekor, M., Monwuba, K. \& Osobu, D., 2012. Rutin Ameliorates Cyclophosphamide-induced Reproductive Toxicity in Male Rats. Toxicology International, 19, $207-214$.

2. Ahmad, A., Husain, A., Mujeeb, M., Khan, S.A., Najmi, A.K., Siddique, N.A., Damanhouri, Z.A. \& Anwar, F., 2013. A review on therapeutic potential of Nigella sativa: A miracle herb. Asian Pacific Journal of Tropical Biomedicine, 3, 337-352.

3. Begum, S.F.M. \& Anuradha, R., 2011. Chemo Protective Action of Asparagus racemosus against Cyclophosphamide Induced toxicity. Research Journal of Pharmaceutical, Biological and Chemical Sciences, 2, 42-54.

4. Bhattacharya, A., Lawrence, R.A., Krishnan, A., Zaman, K., Sun, D. \& Fernandes, G., 2003. Effect of Dietary n-3 and n-6 Oils with and without Food Restriction on Activity of Antioxidant Enzymes and Lipid Peroxidation in Livers of Cyclophosphamide Treated Autoimmune-Prone NZB/W Female Mice. Journal of the American College of Nutrition, 22, 388-399.

5. Chesbrough, M. \& Arthur, M., 1972. Determination of RBC and WBC count.

6. Colvin, M., 2003. Chapter 51. Alkylating Agents and Platinum Antitumor Compounds. In P.R. Kufe Dw, Weichselbaum Rr (ed.) Holland-Frei Cancer Medicine. 6 ed. Hamilton: BC Decker, pp. 949-951.

7. Conklin, K.A., 2004. Chemotherapy-Associated Oxidative Stress: Impact on Chemotherapeutic Effectiveness. Integrative Cancer Therapies, 3, 294-300.

8. Devi, H.P. \& Mazumder, P.B., 2016. Methanolic Extract of Curcuma caesia Roxb. Prevents the Toxicity Caused by Cyclophosphamide to Bone Marrow Cells, Liver and Kidney of Mice. Pharmacognosy Research, 8, 43-49.

9. Drabkin, D.L. \& Austin, J.H., 1935. Spectrophotometric studies: ii. Preparations from washed blood cells; nitric oxide hemoglobin and sulfhemoglobin. Journal of Biological Chemistry, 112, 51-65.

10. E-Article, 2016. NCI Dictionary of Cancer Terms U.S.: National Cancer Institute https://www.cancer.gov/publications/dictionaries/cancer-terms?cdrid=45639.

11. Fraiser, L.H., Kanekal, S. \& Kehrer, J.P., 1991. Cyclophosphamide Toxicity. Drugs, 42, 781-795.

12. Gupta, R.C., Sharma, V., Sharma, N., Kumar, N. \& Singh, B., 2008. In vitro Antioxidant Activity from Leaves of Oroxylum indicum (L.) Vent. -A North Indian Highly Threatened and Vulnerable Medicinal Plant. Journal of Pharmacy Research, 1, 65-72.

13. Hafeman, D.G., Sunde, R.A. \& Hoekstra, W.G., 1974. Effect of dietary selenium on erythrocyte and liver glutathione peroxidase in the rat. Journal of Nutrition, 104, 580-7.

14. Ingale, K.G., Thakurdesai, P.A. \& Vyawahare, N.S., 2013. Protective effect of Hygrophila spinosa against cisplatin induced nephrotoxicity in rats. Indian Journal of Pharmacology, 45, 232-236.

15. Kapoor, L.D., 1990. Handbook of Ayurvedic Medicinal Plants: Herbal Reference Library New York: CRC Press.

16. Khan, G., Haque, S.E., Anwer, T., Ahsan, M.N., Safhi, M.M. \& Alam, M.F., 2014. Cardioprotective effect of green tea extract on doxorubicin-induced cardiotoxicity in rats. Acta Poloniae Pharmaceutica, 71, 861-8.

17. Kumar, K.B. \& Kuttan, R., 2005a. Chemoprotective activity of an extract of Phyllanthus amarus against cyclophosphamide induced toxicity in mice. Phytomedicine, 12, 494-500.

18. Kumar, K.B.H. \& Kuttan, R., 2005b. Chemoprotective activity of an extract of Phyllanthus amarus against cyclophosphamide induced toxicity in mice. Phytomedicine 12, 494-500.

19. Mathew, S. \& Kuttan, G., 1997. Antioxidant activity of Tinospora cordifolia and its usefulness in the amelioration of cyclophosphamide induced toxicity. Journal of Experimental and Clinical Cancer Research 16, 407-411.

20. Mccord, J.M. \& Fridovich, I., 1969. Superoxide dismutase. An enzymic function for erythrocuprein (hemocuprein). The Journal of Biological Chemistry, 244, 6049-55.

21. Menon, S., Lawrence, L., Vipin, P.S. \& Padikkala, J., 2015. Phytochemistryand evaluation of in vivo antioxidant and anti-inflammatory activities of Oroxylum indicum Vent. Root bark. Journal of Chemical and Pharmaceutical Research, 7, 767-775.

22. Mishra, S.L., Sinhamahapatra, P.K., Nayak, A., Das, R. \& Sannigrahi, S., 2010. In vitro Antioxidant Potential of Different Parts of Oroxylum indicum: A Comparative Study. Indian Journal of Pharmaceutical Sciences, 72, 267-269.

23. Moron, M.S., Depierre, J.W. \& Mannervik, B., 1979. Levels of glutathione, glutathione reductase and glutathione S-transferase activities in rat lung and liver. Biochimica et Biophysica Acta, 582, 67-78. 
24. Neboh, E.E. \& Ufelle, S.A., 2015. Myeloprotective activity of crude methanolic leaf extract of Cassia occidentalis in cyclophosphamide-induced bone marrow suppression in Wistar rats. Advanced Biomedical Research, 4, 5.

25. Ohkawa, H., Ohishi, N. \& Yagi, K., 1979. Assay for lipid peroxides in animal tissues by thiobarbituric acid reaction. Analytical Biochemistry, 95, 351-358.

26. Premkumar, K., Abraham, S.K., Santhiya, S.T. \& Ramesh, A., 2003. Protective effects of saffron (Crocus sativus Linn.) on genotoxins-induced oxidative stress in Swiss albino mice. Phytotherapy Research, 17, 614617.

27. Pushpavalli, G., Kalaiarasi, P., Veeramani, C. \& Pugalendi, K., 2010. Effect of chrysin on hepatoprotective and antioxidant status in d-galactosamine-induced hepatitis in rats. European Journal of Pharmacology, 631, 36-41.

28. Ray, S., Pandit, B., Das, S. \& Chakraborty, S., 2011. Cyclophosphamide-Induced Lipid Peroxidation and Changes in Cholesterol Content: Protective Role of Reduced Glutathione. Iranian Journal of Pharmaceutical Sciences, 7, 255-267.

29. Rehman, M.U., Tahir, M., Ali, F., Qamar, W., Lateef, A., Khan, R., Quaiyoom, A., Oday, O.H. \& Sultana, S., 2012. Cyclophosphamide-induced nephrotoxicity, genotoxicity, and damage in kidney genomic DNA of Swiss albino mice: the protective effect of Ellagic acid. Molecular and Cellular Biochemistry, 365, 119-27.

30. Sakthivel, K.M. \& Guruvayoorappan, C., 2015. Acacia ferruginea inhibits cyclophosphamide-induced immunosuppression and urotoxicity by modulating cytokines in mice. Journal of Immunotoxicology, 12, 154163.

31. Sheweita, S.A., El-Hosseiny, L.S. \& Nashashibi, M.A., 2016. Protective Effects of Essential Oils as Natural Antioxidants against Hepatotoxicity Induced by Cyclophosphamide in Mice. PLOS ONE, 11, e0165667.

32. Slavin, R.E., Millan, J.C. \& Mullins, G.M., 1975. Pathology of high dose intermittent cyclophosphamide therapy. Human Pathology, 6, 693-709.

33. Spivak, J.L., Gascón, P. \& Ludwig, H., 2009. Anemia Management in Oncology and Hematology. The Oncologist, 14, 43-56.

34. Stankiewicz, A. \& Skrzydlewska, E., 2003. Protection against cyclophosphamide-induced renal oxidative stress by amifostine: the role of antioxidative mechanisms. Toxicology Mechanisms and Methods, 13, 301-8.

35. Subramaniam, S.R., Cader, R.A., Mohd, R., Yen, K.W. \& Ghafor, H.A., 2013. Low-dose cyclophosphamideinduced acute hepatotoxicity. The American Journal of Case Reports, 14, 345-349.

36. Thews, O., Kelleher, D.K. \& Vaupel, P., 2001. Erythropoietin Restores the Anemia-induced Reduction in Cyclophosphamide Cytotoxicity in Rat Tumors. Cancer Research, 61, 1358-1361.

37. Veerappan, R. \& Senthilkumar, R., 2015. Chrysin enhances antioxidants and oxidative stress in L-NAMEinduced hypertensive rats. International Journal of Nutrition, Pharmacology, Neurological Diseases, 5, 20-27.

38. Warpe, V.S., Mali, V.R., Arulmozhi, S., Bodhankar, S.L. \& Mahadik, K.R., 2015a. Cardioprotective effect of ellagic acid on doxorubicin induced cardiotoxicity in wistar rats. Journal of Acute Medicine, 5, 1-8.

39. Warpe, V.S., Mali, V.R., S, A., Bodhankar, S.L. \& Mahadik, K.R., 2015b. Cardioprotective effect of ellagic acid on doxorubicin induced cardiotoxicity in wistar rats. Journal of Acute Medicine, 5, 1-8.

40. Zhang, D., Zu, Y., Fu, Y., Luo, M., Gu, C., Wang, W. \& Yao, X., 2011. Negative pressure cavitation extraction and antioxidant activity of biochanin A and genistein from the leaves of Dalbergia odorifera $T$. Chen. Separation and Purification Technology, 83, 91-99. 